141

Received: July 19, 2012

Accepted: December 5, 2012
Macedonian Journal of Animal Science, Vol. 3, No. 1, pp. 17-20 (2013)

In print ISSN $1857-6907$

On line ISSN $1857-7709$

UDC:637.12'62.04

Original scientific paper

\title{
PRELIMINARY DATA ON MILK PRODUCTION AND MILK COMPONENTS OF SIMMENTAL BREED IN ALBANIA
}

\author{
Ylli Biçoku', Merita Uruçi ${ }^{2}$ \\ ${ }^{1}$ Agricultural University of Tirana, Tirana, Albania \\ ${ }^{2}$ Albanian Dairy and Meat Association (ADAMA), Tirana, Albania \\ bicokuy@gmail.com
}

\begin{abstract}
The Simmental breed is spread in our country after 2000, through the importation of heifers and biological material, mainly from Austria and Germany. One of the reasons, for the actual prevalence of this is its direction of combined milk-meat, suitable for the conditions of small and medium private farms. Our study was to analyze the milk production, and the link of this product with key ingredients such as milk fat, protein, and freezing point produced by cows imported from Austria in 2007, and bred on private farms in the Kruja and Durres districts. For the period September 2010 - April 2011 the milk of 18 in both farms was analyzed. The analysis of milk production in the farm of the Kruja district in 2007-2008 (3.800 liter/cow) noticed that we had to do with a herd that produced 50\% more milk than average milk production in the country, but with higher potential. Likewise, the yield of these cows for lactation 2010-2011 was 5.400 liters/cow/year. The data of our study for milk fat, protein and freezing point are within the limits of the Albanian Standards and EU Directives, and higher compared with the results taken by other Albanian authors, during the period from 1996 to 2000 . However, the milk fat and protein percentage are lower compared with the results taken in Austria which could be explained with the management and nutrition conditions that are not on the level of the requests. There is not statistically significant relationship between milk production and milk fat at the $95.0 \%$ or higher confidence level. The correlation coefficient equals 0.0354184 , indicating a relatively weak relationship between the variables; but there is a statistically significant relationship between milk production with protein content and the freezing point. Statistical data processing was done with the Statgraphics Centurion XVI.
\end{abstract}

Key words: breed; milk fat; protein; freezing point; milk production

\section{ПРЕЛИМИНАРНИ ПОДАТОЦИ ЗА ПРОИЗВОДСТВОТО НА МЛЕКО И НЕГОВИТЕ СОСТОЈКИ КАЈ СИММЕНТАЛСКАТА РАСА ГОВЕДА ВО АЛБАНИЈА}

\footnotetext{
Сименталската раса започна да се шири во нашата земја по 2000-та година, преку увоз на јуници и биолошки материјал, главно од Австрија и Германија. Една од причините, за распространетоста на оваа раса е нејзината комбинирана насока млеко-месо, погодна за условите на мали и средни приватни фарми. Нашата студија беше да се анализира производството на млеко, и врската на овој производ со клучните состојки како што се млечни масти, протеини и точка на змрзнување произведени од кравите увезени од Австрија во 2007 година, и одгледани на приватни фарми во областа Круја и Драч. За периодот септември 2010 - април 2011 година беа анализирани 18 проби на млеко и во двете фарми. Од анализата на производство на млеко на фармата во Круја во 2007-2008 (3,800 литри/крава) забележавме дека имавме случај со стадо кое произведува $50 \%$ повеќе млеко од просечнато производство на млеко во земјата, но со повисок потенцијал. Исто така, приносот од овие крави за лактација во 2010-2011 е 5,400 литри/крава/година. Податоците од нашата студија за млечни масти, протеини и точката на замрзнување се во рамките на албанските стандарди и директивите на ЕУ, и повисоки споредено со резултатите направени од страна на други албански автори, за време на периодот 1996-2000 година. Сепак, процентот на млечни масти и протеини е понизок во споредба со резултатите направени во Австрија кои може да се објаснат со начинот на управување и условите на исхрана кои не се на нивото на барањата. Не постои статистички значајна врска помеѓу млекопроизводството и млечни масти во 95,0\% или повисоко ниво. Коефициент на корелација е еднаков на 0.0354184 , што укажува на релативно слаб однос помеѓу променливите вредности, додека постои статистички значајна врска помеѓу млекопроизводството со содржината на протеини и точката на замрзнување. Статистичка обработка на податоците беше направена co Statgraphics Centurion XVI.
}

Клучни зборови: раса, млечни масти, протеини, точка на мрзнење, млеко. 


\section{INTRODUCTION}

In the last decade there is a tendency of establishment of farms for milk production with a capacity of 10-100 head of milking cows. The Simmental breed is largely extended in the farms located in western lowlands of the country.

The development of livestock in general as well as of milking cows, including in particular the dual purpose breeds, is related with several factors, where some would as mentioned be souch: Albanian tradition in animal breeding; needs requirements for animal origin products for family consumption, as well as for the market; daily income from selling milk and young calves as a good source of revenues.

The milk yield from the cows was not increased significantly in Albania in the last 20 years (in the year $1991-1395 \mathrm{~kg} /$ milk per cow, whereas in the year $2010-263 \mathrm{~kg} / \mathrm{cow}$ ), as their feeding was unsatisfactory. The farmers mainly use fresh fodder and hay, of a relatively low quality. Concentrated feed is used in insignificant quantities, even in the case when it is used by farmers who supply corn and wheat bran to their animals, which results from lack of tradition as well as from by rather high price of concentrated feed.

\section{MATERIAL AND METHODS}

In the study 18 head of milking cows of the Simmental breed of two herds in the central part of Albania (districts of Kruje and Durres) were taken. Only the milk production and its main ingredients (protein, fat and freezing point), were studied as only these data were available.

Such analyses are indispensable as the Simmental breed, taken in the study, comes for the second time in our country, but for the first time was not studied for some of the above mentioned indicators.

Regarding the choice of milking cows' farm it would be emphasized that it was taken in the study as the farm was located in the central part of Albania where the climatic conditions did not differ from the western lowland part where there are other farms. The second reason is that the owners were ready to provide the data at our disposal.

Data statistic processing was carried out with the Statgraphics Centurion XV.

Taking samples, determination of fat, protein, and the freezing point was were carried out according to the standard method of the analysis SMEDP (AOAC).

\section{RESULTS AND DISCUSSION}

From the analysis of milk production, of both herds, for the lactation period of 2010-2011, high results for the breed, 5400 liter/head are obtained. The genotype of their parents (mother and father) shows their origin from milking cows with high productive quality of the Simmental breed. The average production and body live-weight are close to the breed standard and likely should be named a herd of high milk production. There is a large variation of parameters, within the herd, in compliance with normal distribution of such herds in the fed system based on voluminous feed (hay and fresh fodder) with not a high amount of concentrated feed.
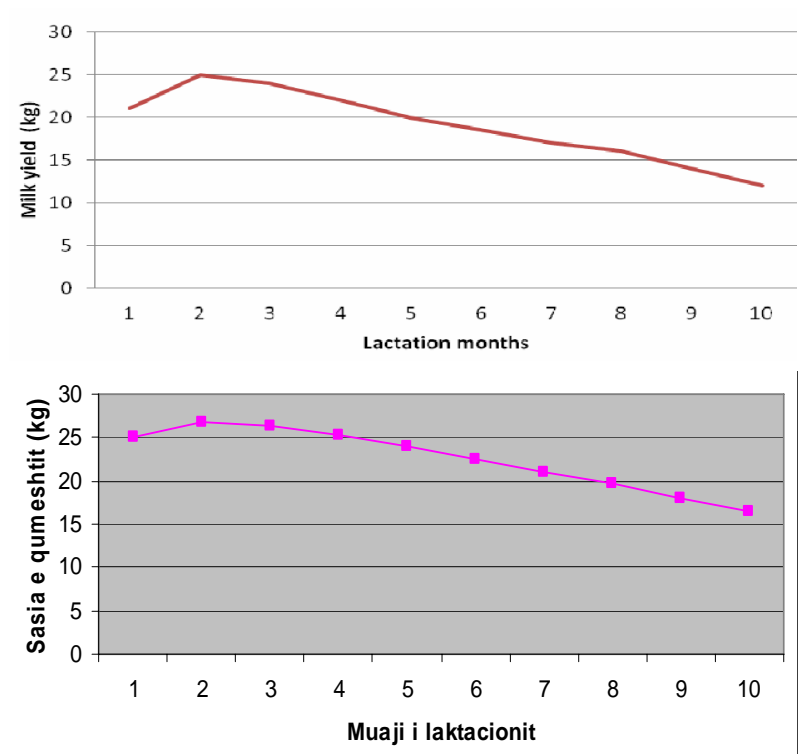

Fig. 1. Lactation curve of the studied herd compared with the theoretical one

For the period from September 2011 to April 2012, 144 samples from 18 cows under control were taken and analyzed, the average value of which are given in the following table .

Table 1

Milk components for the studied herd

\begin{tabular}{lccc}
\hline \hline & Fat (\%) & $\begin{array}{c}\text { Protein } \\
(\%)\end{array}$ & Freezing Point \\
\hline Mean & 4.08 & 3.32 & -0.5102 \\
Limit & $3.20-5.17$ & $3.1-3.6$ & $-0.480--0.531$ \\
\hline \hline
\end{tabular}

The relationship milk production - fat indicator. It is the most variable part of milk. From our data the percentage of fat is lower in July and 
higher in March. The data from literature (Heinrics J. et al., 1997; Allore et al., 1997; as well as Bailey K., 2005) show that the lowest level of milk fat is between the first 25 and 50 days of lactation, reaching the highest level in $8^{\text {th }}$ month of lactation and then it starts to decrease.

So, it is noticed that average percentage of the fat of these cows $(4.08 \%)$ is above the level defined in Albanian standard for cow milk. This indicator is higher even from the average obtained (3.8 and $3.5 \%$ ) of both studies carried out by the Institute of Food Research (IFR) for the years from 1996 to 2000 in some districts of the country, as well as it is approximated with fat percentage in the country origin $(4.2 \%)$. Since the P-value in the ANOVA table is greater or equal to 0.05 , there is not a statistically significant relationship between $\%$ of Milk Fat and Milk Production at the 95.0\% or higher confidence level.

The correlation coefficient equals 0.0354184 , indicating a relatively weak relationship between the variables. $\left(n=144, P=0.6734, R_{2}=0.125446\right.$, $\left.Y=a+b^{*} X\right)$. Although, according to some authors (Analla et al., 1996; Heinrichs J. et al.,. 1997; Metz V. I. et al., 2001) genetically links between milk production and the fat content are -0.89 , which indicate strong negative links between both indicators, whereas the phenotype correlation is are -0.48 .
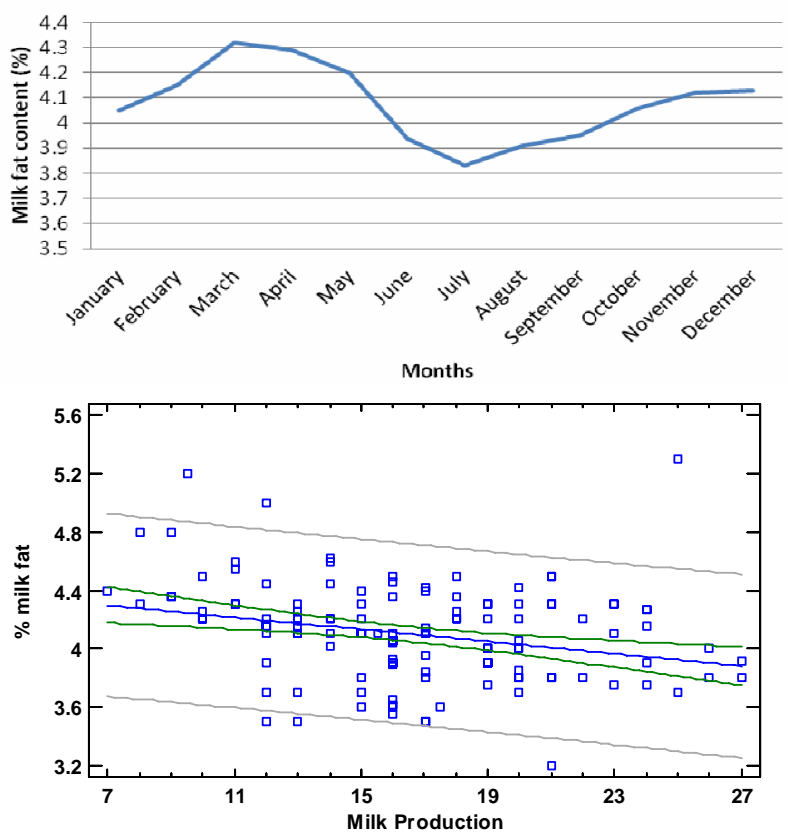

Fig. 2. Milk fat content during the year

Relationship milk production - protein indicator. From the data it is noticed that average percentage of protein of these milking cows (3.32 $\%)$ is above the level determined by Albanian standard for cow milk (28 gr per liter), as well as above level $(2.91 \%)$ taken from studies of Institute of Food Research during the years 1996-2000. This indicator is lower than average percentage of protein in the country of origin $(3.45 \%)$, where the level of feeding has a significant role, which is not the same with the country of origin.

Since the $P$-value in the ANOVA table is less than 0.05 , there is a statistically significant relationship between $\%$ protein and milk production at the $95.0 \%$ confidence level.

The correlation coefficient equals -0.417852 , indicating a relatively weak relationship between the variables. $\left(n=144, P=0.0000, R^{2}=17.46\right.$, $\left.Y=a+b^{*} X\right)$.

According to some authors (Welper and Freeman, 1992; Analla et al., 1996; Heinrichs J., et al., 1997; Metz. V. I. et al., 2001) genetically links between milk production and protein content are -0.65 ; whereas the phenotype correlation -0.47 .
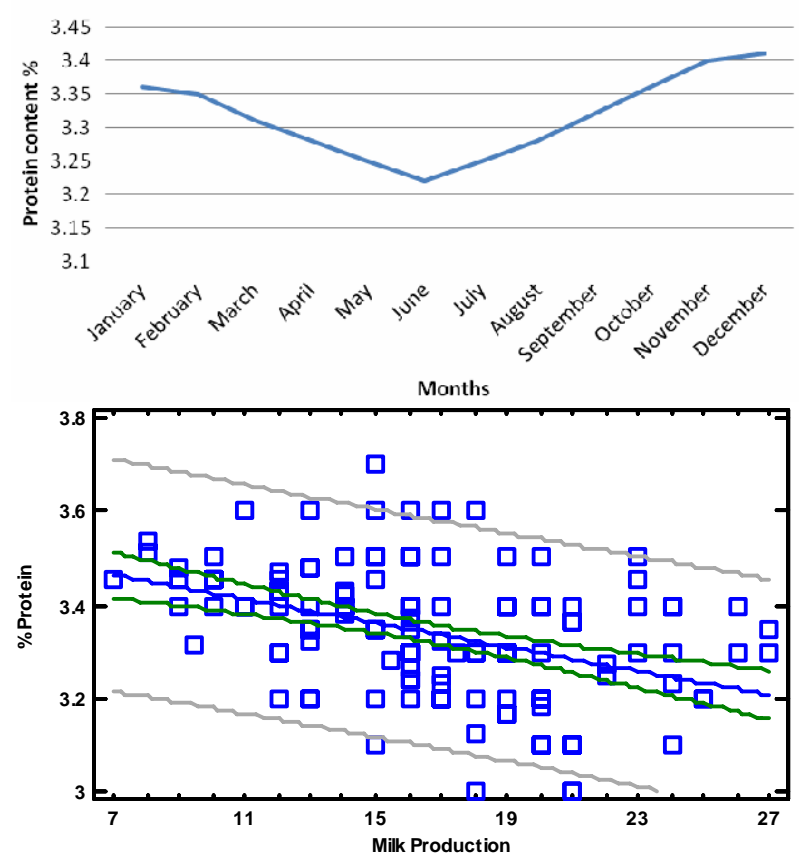

Fig. 3. Protein content during the year

Relationship milk production - Freezing point of milk (freezing point/freezing index). Presence of added water in the milk is illegal. The measurements of milk freezing point ensure the best means to impose/find the amount of water added in the milk. The freezing point of milk is considered as a more constant physical parameter and for this reason it is used largely in dairy industry to find the mixture of milk with water. The fre- 
ezing point (freezing temperature of milk) is less than $0^{\circ} \mathrm{C}$ as a result of lactose and mineral matter content, which are rather constant. The freezing point is close to $0^{\circ} \mathrm{C}$ when in the milk is added water.

Based on the Regulation EC 85/307 the level of freezing point should be $-0.530^{\circ} \mathrm{C}$, whereas the acceptable value not suspected for water adding is $-0.520^{\circ} \mathrm{C}$.

The objective of the study was the examination of the relationship of this indicator with milk production. During control as a comparative point for water level $0 \%$ was taken the value of temperature $-0.512^{\circ} \mathrm{C}$, which is recommended from literature as a minimum value for normal milk.

In fact, the milking cows taken in the study provided an indicator with a value of -0.5102 that for the conditions of our country is rather acceptable. So, this indicator from the studies carried out by the Institute of Food Research in the years from 1996 to 2000 is on the level -0.408 up to -0.514 . From different authors (Giangiacomo, R 2000) it is emphasized that values above $-0.520^{\circ} \mathrm{C}$ (as much closer the value of $0{ }^{\circ} \mathrm{C}$ ) are suspicious.

Since the $P$-value in the ANOVA table is less than 0.05 , there is a statistically significant relationship between the Freezing Point and Milk Production at the $95.0 \%$ confidence level. The correlation coefficient equals -0.305931 , indicating a relatively weak relationship between the variables $\left(n=144, P=0.0002, R^{2}=9.35935, Y=a+b^{*} X\right)$.

The continuation of work and the opportunity to ensure equipments and other laboratories in different areas of the country enable to collect necessary materials in order to establish a real norm in our standard

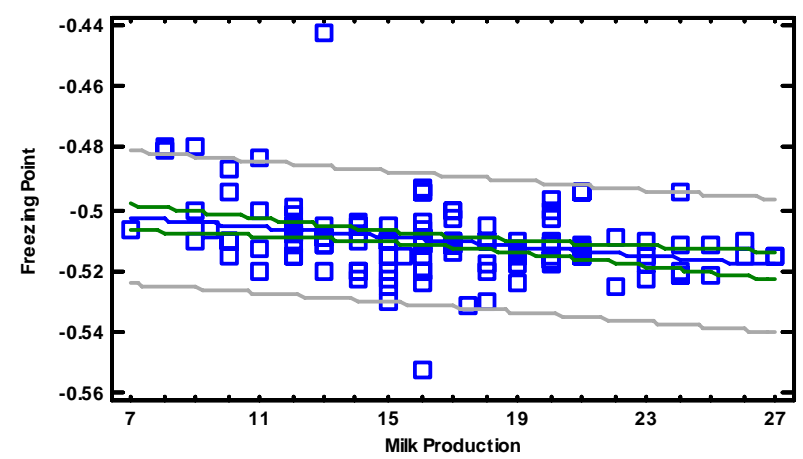

Fig. 4. Plot of fited model freezing point $=-0.497279-0.00079691 *$ milk production

\section{CONCLUSIONS}

From our data the indicator of milk fat, protein and the freezing point are within the limit of the state standard and the EU directives, as well as the highest compared with the studies of other local authors. Nevertheless the percentages of fat and protein are lower comparing with those of the country of origin which is explained with the lower level of feeding and management in general.

There is not statistically significant relationship between Milk production and Milk fat and at the $95.0 \%$ or higher confidence level. The correlation coefficient equals 0.0354184 , indicating a relatively weak relationship between the variables; while there is a statistically significant relationship between Milk Production with Protein Content and the Freezing Point however in both cases the correlation coefficient $(-0.417852$ and -0.305931$)$, indicators a relatively weak relationship between the variables.

\section{REFERENCES}

[1] Bjerg, M., Rasmussen, M. D., Nielsen, M. O. (2005): Changes in Freezing Point of Blood and Milk during dehydration and Rehydration in Lactating Cows. J. Dairy Sci. 88, 3174-3185.

[2] Giangiacomo, R. (2000): Milk Testing, Quality Control, Hygiene and Safety. - Istituto Sperimentale Lattiero Caseario - Lodi, Italy. Small Scale Milk Collection and Processing in Developing Countries Conference, Discussion Paper 1.3: FAO Conference, Proceedings.

[3] Heinrichs, J., Jones, C., Baily, K. (1997): Milk Components: Understanding the Causes and Importance of Milk Fat and Protein Variation in Your Dairy Herd. The Pennsylvania State University.

[4] Kędzierska-Matysek, M., Litwińczuk, Z., Florek, M., Barłowska, J. (2011): The effects of breed and other factors on the composition and freezing point of cow's milk in Poland. International Journal of Dairy Technology, 64, 3, 336-342.

[5] Metz, V. I., Coulon, J. B., Pradel, P. (2001): Relationship Between Milk Fat and Protein Contents and Cheese Yield. , INRA, EDP Sciences, Anim, Res. 50, 365-371.

[6] Mustafa, A. (2001): Feeding the Dairy Cow During Lactation. Dairy Production, 342-450A, Department of Animal Science McGill University.

[7] Pinguli, E., Ymeti, Y., Bujari, V. (2001): Vlerësimi i Nivelit Cilësor të Qumështit Lëndë e Parë në Kushtet e Zhvillimit të Ekonomisë së Tregut në Shqipëri. Referuar në Konferencën Nderkombëtare Cilësia dhe Siguria Ushqimore, Tiranë, 21-22. 9. 2001.

[8] Rinderzucht Austria, Recording Results of the Austrian Cattle Breeds (2005).

[9] Standardi Shteteror I Republikes Se Shqiperise: SSh 1563-87.

[10] Teger, G. S., Lavrenčić, A., Grahelj, A. (2005): Freezing point of milk in a herd of high yielding dairy cows. Mljekarstvo, 55, 2, 125-138.

[11] Welper, R. D., Freeman, A. E. (1992): Genetic parameters for yield traits of Holsteins, including lactose and somatic cell score. J. Dairy Sci. 7. 